$11-2002$

\title{
Designed Physical Environments as Related to Selves, Symbols, and Social Reality: A Proposal for a Humanistic Paradigm Shift for Architecture
}

\author{
Ronald Smith \\ University of Nevada Las Vegas, ron.smith@unlv.edu \\ Valerie Bugni \\ Lucchesi Galati Architects
}

Follow this and additional works at: https://digitalscholarship.unlv.edu/sociology_pubs

Part of the Architectural History and Criticism Commons, Environmental Design Commons, Industrial and Organizational Psychology Commons, and the Place and Environment Commons

\section{Repository Citation}

Smith, R., Bugni, V. (2002). Designed Physical Environments as Related to Selves, Symbols, and Social Reality: A Proposal for a Humanistic Paradigm Shift for Architecture. Humanity and Society, 26(4), https://digitalscholarship.unlv.edu/sociology_pubs/6

This Article is protected by copyright and/or related rights. It has been brought to you by Digital Scholarship@UNLV with permission from the rights-holder(s). You are free to use this Article in any way that is permitted by the copyright and related rights legislation that applies to your use. For other uses you need to obtain permission from the rights-holder(s) directly, unless additional rights are indicated by a Creative Commons license in the record and/ or on the work itself.

This Article has been accepted for inclusion in Sociology Faculty Publications by an authorized administrator of Digital Scholarship@UNLV. For more information, please contact digitalscholarship@unlv.edu. 
Published In Humanity and Society, vol. 26, no.4. Nov, 2002, pp. 293-311

DESIGNED PHYSICAL ENVIRONMENTS AS RELATED TO

SELVES, SYMBOLS, AND

AND SOCIAL REALITY: A PROPOSAL FOR A HUMANISTIC

PARADIGM SHIFT FOR ARCHITECTURE

Valerie Bugni

Organizational and Social Researcher

Lucchesi Galati Architects, Inc.

Las Vegas, Nevada

Ronald W. Smith

Chair, Department of Sociology

University of Nevada, Las Vegas

\section{REFLEXIVE STATEMENTS}

BUGNI: For many years, I have collaborated with architects and other design professionals in the marketing, planning, programming, and evaluation of buildings. As part of this work, I have had numerous opportunities to observe and critique the process of building design. In project after project, I have seen major gaps and disconnects in the process of creating humanized spaces for people. These observations have prompted me to research and write about the impact of architecture in our lives; its influence on the development of self, organizations, and communities; and its potentiality in changing and elevating the human condition. 
SMITH: My research interests focus on the social psychology of organizations, organizational culture, organizational performance and development, and community sociology. As a result of this research and the administrative positions I have held, I am convinced that social scientists need to converse far more with architects about how their theories and research apply to the design of physical structures and places. We need to convey how these environments impact people, and especially how self definitions and expressions of self are affected, and to demonstrate how people simultaneously construct meaning for their physical structures and places. We need, however, far more than just talk about such matters. We need to show how designed physical environments can be humanized and we need to convince architects that their profession has much to gain from this shift in design approach.

Authors' note: Authorship of this article is equal

\section{INTRODUCTION}

\section{"Social beings are things as definitely as physical things are social."} -George Herbert Mead (1932)

At a recent roundtable discussion on space planning and workplace trends the featured speaker was a prominent interior designer for one of the world's largest office furniture manufacturers. During the presentation, the designer made a statement which in our minds signifies what is wrong with contemporary architectural theory and practice, "Our space planning approach concerns itself with facility and human performance measures...however, excluded from our analysis are factors such as behavior and meaning." When an audience member asked why his firm's approach excluded these two factors, the speaker replied, "Behavior and meaning are too difficult to study."

Contrary to this belief, sociologists, psychologists, and anthropologists have since the early 1950s conducted extensive research and subsequently gained valuable insights as to how human thinking and conduct are related to designed physical environments. Environmental psychology has a long history of studying the relationship between individual and the physical environment, and has learned much about an individual's awareness, cognitive maps, attitudes, preferences, participation, stresses and coping mechanisms, and performance in environments (Gifford 2002, Franck and Lepori 2000, and DeYoung 1999). Environmental anthropology has given attention to socio-cultural behavior in specific environments, and has gained understanding about cultural diversity in communities and the sometimes opposing values, beliefs and norms of interest groups (Crumley et al 2001). In sociology various subfields concerning the environment have emerged. For example, "Human ecology" gained prominence during the 1930s and examined how competition among groups within the urban environment resulted in rather 
predictable residential and land use patterns (Park 1936 and Hawley 1986). More recently, sociologists using "political economy models of urban environments" have demonstrated how economic and political elites, and their use of power, negatively impact the needs of community residents (Feagin 1988 and Smith and Timberlake 1997). "Environmental sociology" has focused on the overexploitation of the ecosystem, resource depletions, the role of capital accumulation in environmental destruction, and environmental movements (Catton and Dunlap 1978; Buttel 1987; and Gottdiener and Hutchison 2000); "Organizational ecology" has studied how the physical design of workplace organizations impacts workers, and work processes and performance (Becker and Steel 1995; Sommer 1983); and "Architectural sociology" has focused on how groups, such as organizations, are both influenced by and in turn influence designed environments. These sociologists apply their theories and research methods to all the stages of the architectural project-from predesign to post-construction evaluation (Bugni and Smith 2002).

Numerous research and think-tank organizations also have emerged to support person-environment research. The Environmental Design Research Association (EDRA) was established in 1968 and grew out of the work of environmental psychologists. This international organization now consists of design professionals, various types of behavioral scientists, educators, students, and facility managers. Returning to the interior designer's comment, it is clear that behavior and meaning has been studied and measured quite effectively.

Ironically, despite all this multi-disciplinary human-environment focus, architects and other design professionals have been accused of being unwilling to incorporate this knowledge into their design approaches and methods. Some three decades ago Arnheim (1977) argued that designers were creating spaces through formalistic practices, or the tendency to treat buildings as pure shape and without regard to their human and practical functions. Apparently, many critics within architecture today believe that not much has changed in this regard. John Morris Dixon, long time editor-in-chief of Progressive Architecture, and now titled Architecture Magazine, recently voiced the same misgivings about beautifully designed creations that are absent human considerations, "What the world needs now from architects is not personal statements but effective solutions for the housing of human activities and the organization of communities" (Dixon 2003).

We would challenge the architectural profession to move from formalism to humanism as a theory of practice, and ask that these professionals consider the most fundamental logic that becomes the basis for this paradigm: First, A large proportion of human interaction and social experience takes place in designed physical environments, and there is a seemingly endless variety of these environments where this interaction and experience occurs. Second, the self is created and expressed through an ongoing process of interaction and social experience (Mead 1934). And, third, our designed physical 
environments are related to the self and its expression as well as our shared symbols and meanings for life. ( Gieryn 2000; Bordieu 1990; and Giddens1990).

In this paper we will begin by briefly describing the concept of self, proceed by discussing the symbolic significance of physical environment, then describe as well as propose a humanist paradigm which we believe should be employed in architectural theory and practice, and finally discuss how the shift to a humanistic paradigm might be accomplished.

\section{THE NOTION OF SELF}

In the late 1800s psychologist William James was one of the first scholars to write extensively on the topic of self (Brown 1998). He defined the "empirical self" as the many ways individuals think about themselves. James cataloged the empirical self into three subcategories--the "material self" referred to the tangible objects, people, or places that influence the self; the "social self" referred to how we are regarded and recognized by others; and the "spiritual self" referred to our inner self.

Shortly thereafter sociologists became equally fascinated with the subject. Charles Horton Cooley (1902) wrote about the "looking-glass self" as consisting of the imagination of another person's judgment of his or her appearance and the resulting selffeeling such as pride or mortification. George Herbert Mead (1934) extended Cooley's ideas and defined the self as being part of a social developmental process - the self is not present at birth, but rather the self can only develop through a process of social experience and activity (Mead 1934). Central to Mead's discussion is the idea that not only is the self a social object, but it also has potential to change because it continues to be defined and redefined as interaction with others proceeds. Stryker (1959) later maintained that how people view themselves is a process; the self is a continuously changing object that is dependent on the social situations and definitions encountered in everyday life. Implicit in the discussions of these early scholars is that these definitions and situations involve one's physical environment.

A more active view of the self, and one that directly refers to the physical environment-self relationship, is shown in the work of Erving Goffman (1959). He defines "impression management" as the efforts of people to manage the impressions others form of them during performances within the physical confines of a building or plant (Goffman 1959: xi). Goffman refers to the "performances" humans create while in the presence of others to influence and manipulate their impressions of the actor. The "front" region is the part of the individual's performance created to define the situation for the audience. In this region, the "setting," or the physical environment, includes place and layout, furniture, decorations, and any other prop-like instruments, which help "set the stage" for the front region to be displayed. Meanwhile the "back region" is a guarded place from which the performance is created. Here, action occurs that may be 
inconsistent with the appearance fostered by the performance. Goffman also observes that certain performances require the use of duel regions. He states, "Thus, the private office of an executive is certainly the front region where his status in the organization is intensively expressed by means of the quality of his office furnishings. And yet it is here that he can take his jacket off, loosen his tie, keep a bottle of liquor handy, and act in a chummy and even boisterous way with fellow executives of his own rank"( Goffman 1959: 126).

Goffman's work suggests that the presentation of self is created to define situations and influence audiences. We stage a performance -- to control the impression given to and taken by onlookers through the use of costumes, facial expressions, gestures, moods and demeanors and, most pertinent for our purposes, through manipulation of one's physical environment.

The foundational work about self has revealed that the self is an evolving state by which one comes to define himself or herself as an object among other social objects. The self is constructed as we participate in a cognitive, symbolic, and physical world. The individual seeks to understand self via his reflexive world of meanings created through mental processes, social interactions, and shared symbols. For our purposes it is especially important to note that the search for constructing and understanding the self (e.g., cognitive processing, conversing with others, and sharing common meanings) occurs within a physical environment and the environment itself can convey meaning that impacts self definitions. Finally, the early discussions of self revealed that we can create and use different impressions of self as audiences and situations change, and that we actively use our physical environments to help manage these impressions.

\section{THE SYMBOLIC SIGNIFICANCE OF PHYSICAL ENVIRONMENT}

"We shape our buildings and afterward our buildings shape us"

Winston Churchill reflecting about the bombed Houses of

Parliament and the importance of democratic institutions (1944).

The meanings we give to objects, buildings and places in our physical environment and in turn the meanings the physical environment provides for our self definitions, shared symbols, and shaping of our actions are perhaps best explained by "symbolic interactionism." This theoretical perspective suggests that human beings exist in a symbolic environment of social objects and shared language and that humans shape and reshape reality through interaction with these objects, self, and others (Cooley, 1902 and Mead, 1934). Blumer (1969) declared that symbolic interactionism rests on three premises: First, human beings act toward things on the basis of the meaning that the things have for them. Second, the meaning of things is derived from, or arises out of social interaction. Third, meanings can change over time as interpretive processes are 
modified. Blumer (1969) also observed that objects are of three types—-"physical objects" such as buildings, desks, or hallways; "social objects" such as professors, students, or architects; and "abstract objects" such as integrity, compassion or control. According to Blumer, the nature of all objects (in all three categories) has meaning for the person or persons for whom it is an object.

Organizational theorist Mary Jo Hatch links the basic tenets of symbolic interactionism to understanding the physical structure of organizational life. In her book, Organization Theory (1997), she discusses two approaches to the study of physical environment within organizations. The "behavioral approach" sees behavior as being shaped by the design of a physical environment, and the "symbolic approach" sees the physical environment as containing cues that communicate messages to people reminding them of their expected roles. Hatch comments about the symbolic meaning of the physical environment within an organization, "Those who adopt the symbolic view see the physical structure of an organization as shaping and maintaining a system of meaning that helps organizational members to define who they are and what they are doing" (1997:251).

Urry (1991) provides a similar argument and maintains that buildings have the potential to help occupants construct meaning and what they feel. Pasquale Gagliardi in his essay, "Exploring the Aesthetic Side of Organizational Life" which builds upon Csikszentmihalyi and Rochberg-Halton's (1981) study of transactions between people and things, also argues that material reality performs a significant role in influencing constructions of self. He also points out an important causal loop or feedback process wherein individuals in turn perceive and give meaning to material things. As an example of Gagliardi's latter assertion, we recall one recent design project that involved the programming, design, and construction of a new office for a local newspaper operation. The newspaper group decided to move from an older office building to a new high-rise office building, and the executive editor, who had been writing for the newspaper for some 40 years, did not want to part with his 40-year old desk. For him, the desk represented more than a desk - it represented the meaning of his life.

In workplace and other organizational studies there have been historical ebbs and flows regarding interest in studying the physical environment's impact on human activity. Beginning in the early 1900s, scientific management and classical administration theories were influential in determining the design and management of work. Management viewed workers as being machinelike either efficiently or inefficiently producing output, and as an outcome of these views industrialists began to develop standardized work processes and architects sought to design standardized and efficient work environments (Montana 1993).

The study of work environment continued until the famous "Hawthorne Experiments" of the late 1920s and early 1930s (Stallworth 1996). These experiments, 
conducted by Elton Mayo and his colleagues at Western Electric's Hawthorne plant near Chicago, were originally designed to examine the effect of illumination on worker productivity. As expected, when illumination was increased, productivity increased, but when illumination levels were reduced, worker productivity did not decrease as was predicted by the researchers but in fact continued to increase. Mayo and his associates concluded that managerial attention was seen as gratifying by workers and therefore it was "social influences" that had the largest impact on worker productivity (Mayo 1945). Among later organizational theorists this so called "Hawthorne effect" led to increased emphasis on studying human relations and decreased interest in examining the physical environment of organizations (Gifford 1997; Hatch 1997; Stallworth 1996). However, it was sociologist George Homans (1950) who later noted that the social effects discovered by the Hawthorne researchers were in fact initiated by a change in the physical environment (i.e., the workers were relocated to a new space for the experiment and illumination was the environmental stimulus employed). Thus, Homans argued that physical environment took on a new meaning to workers and set in motion the dynamics of a changed human response. Homans has provided a more complex and accurate interpretation of the original Mayo findings-one that links physical environment and social causality.

The study of the physical environment lay relatively dormant until the Civil Rights Movement triggered the birth of the "social design" in the 1960s. During this tumultuous time issues of race and gender inequality, civil rights, environmental damage, and a variety of injustices and problems caught the public's attention. Thus, the social design movement arose at this time to correct misalignments between people and their built environments. Sommer (1983), an environmental psychologist, described social design as the process of creating physical environments that meet the social and physical needs of the occupants. He argued that since physical design of space strongly influences behavior, behavioral scientists should play an integral role in the design process. Interestingly, during this time period architects in fact began to invite behavioral scientists into the design process to help them better understand the human-environment relationship. Sommer's research points to our broader thesis: one that suggests physical environment and all of objects that comprise it potentially have associated symbolic significance. Architecture involves more than the construction of a building--it involves construction of social reality (Cuff 1966). Sociologist Thomas Gieryn illustrates these points, "Buildings don't just sit there imposing themselves. They are forever objects of (re) interpretation, narration and representation....Buildings... sit somewhere between agency and structure (2002:35).

Social and environmental psychologists and others continued to study the relationship between the physical environment and human thought and behavior during the 1970s and 1980s. For example, Steele $(1973,1983)$ addressed the variety of functions provided by physical environment for human well-being. According to Steele (1973), a 
space affects an individual by providing opportunities for security and shelter, social interaction, symbolic identification, task performance, pleasure, and growth. According to Steele, "security and shelter" referred to the space providing a sense of safety for the occupants, such as a roof protecting the person from the natural elements. "Social interaction" referred to the space allowing occupants the opportunity to gather and meet with examples being a town-square or an office meeting room. "Symbolic identification" referred to the direct and subtle messages sent by the space. For example, a large executive suite within an office setting would indicate a hierarchal type organizational structure. "Task performance" referred to the appropriateness of the space for the task to be performed, such as the use of a soundproof room when recording music. "Pleasure" involved the way in which the space stirs emotional response within the hearts and souls of the occupants. Garden settings or sunrooms often elicit such pleasures. And, "growth" referred to the self-knowledge and self-awareness acquired when using the space. Perhaps to devoted and knowledge-hungry readers a home library would be an example of such an environment. More recent humanist scholars have extended Steel's concepts in their discussions of physical objects. For example, French philosopher and post-modernist Jean Baudrillard (1981) writes about the seductive power of physical objects as sources of pleasure and passion, and about the logic of objects having use value, exchange value, symbolic exchange value, and sign value. And, Lorraine Daston, Director of the Max Planck Institute of History and Science, writes about the courses that objects take generating trails of symbolic attachment, identity, and investment across time and space ( Burrell 2002:357).

Thus, we see that symbolic interactionism and related research findings clearly indicate a connection between our physical environments and our definitions and performances of self, the symbols and meanings we come to share, and our subsequent behavior. Thus, we might reasonably assume that this people-centered perspective would be widely used in contemporary architectural thought and practice. As we noted earlier, however, many within the design profession dispel this assumption. Arnheim (1977), Sommer (2001), Franck (2000) and Dixon (2003), among others in the design world, would share the belief that those who now design physical environments have not changed a great deal and, in fact, architecture has reverted back to formalism. Franck and Lepori (2000) state, "For some time now in architecture the outside perspective has taken precedence, giving far more importance to form, idea, and appearance than to ways of living, to occupants' needs, and embodied experience. The tradition of architecture as autonomous objects that is so clearly present in books, magazines and many buildings today neglects one of the reasons for architecture to exist at all - the enclosing of human activity. Architects remain on the outside, creating the building as an object, looking at it but not imagining its inhabitation. They become only spectators, projecting their ideas upon the world, rather than discovering what is already there or could emerge."

\section{FROM FORMALISM TO HUMANISM}




\section{"Architecture is a social art..."}

Robert Hershberger (1999)

It is time for a fundamental shift in the way architects view and practice architecture. It is time for a shift from formalism to humanism. The humanist approach provides for an architectural theory of subjective meaning rather than that of formal objective reality. The architecture of subjective meaning elevates the architectural process by providing an opportunity to probe more deeply into place-self relationships prior to the formation of the design solution. A humanistic approach focuses on how the needs, interests and ideals of people can be fulfilled by physical design. The humanist approach views the building as an active participant in the lives of actors and which allows human potential to unfold. The humanistic approach sees architecture as an agent for social transformation improving the quality of people's lives. In contrast, the architecture of formalism reduces the design process to the creation of autonomous objects, giving far more attention to form, fame, service fees, award recognition, speed, and efficiency than to the processes of personal, organizational, and social transformation.

Our appeal for a humanist paradigm in architecture is hardly new or unique. During the 1970s prominent architect Phillip Johnson, who was a strong proponent of the formalistic approach to design, said "The job of the architect is to create beautiful buildings. That's all" (Davis, 1971). And, a decade later Sommer criticized formalism as the creation of "hollow sculptures" without "any trace of human presence" (1983:4). There are reasons why decades of architectural practice models have not embraced the humanistic paradigm--the design process to many has become little more than a supplyside commodity, many architects believe that their creative designs should take precedence over the interests and needs of users, the training of architects ignores social science theories and research methods, and some architects believe the humanistic model is just another fad without long-term value.

We argue that the humanistic approach would better enable clients to understand the designed project from a more personal and therefore meaningful perspective--a perspective beyond formalism and inclusive of humanism that allows for a micro view of the relationship between physical environment and one's self. We contend also that the humanistic perspective also holds many advantages in regard to building and place design for new organizations and organizations wishing to transform. In this regard, architecture should involve more than the programming and design of spatial requirements and physical adjacencies as proscribed by the formalist tradition. The design process should involve a comprehensive evaluation of an organization's entire system, including its various members (e.g., owners, managers, workers, clients, and the public), goals, tensions, cultures, work processes, technologies, networks of communication, control structures, linkages to other organizations, and financial resources. This approach to organizational inquiry would include such questions as: What is the building's primary 
purpose for being? How will the building's design support the core mission, vision, and evolutionary process of the organization and its people? How will the design help the organization and its people transform? How can the culture of the organization be reflected in the space plan, interior design, and form of the building? How will the building's design support and enhance the organization's operational processes? Can the architectural design contribute something larger to the society beyond just providing a container for people? What will the newly constructed buildings convey about us as a community and as a society?

We would argue that design professionals have the obligation to build structures and places that provide for meaning and fulfillment, where both individual self and organizational life can thrive. We would argue from the humanistic perspective that the architect's most fundamental role is to support people, organizations, and society.

\section{ACCOMPLISHING THE SHIFT TO HUMANISM}

"I certainly agree that architects and designers need more information about people and their activities and experiences and how design may support and enhance them. However, even all the best information possible presented in ways architects can easily use will be useless unless we want it. For that to happen,

there needs to be a change in attitude. -Karen A. Franck and Bianca Lepori (2000)

Beyond the calls for a humanistic paradigm shift, we must also clearly demonstrate to design professionals in the most immediate and practical ways the advantages of the humanistic perspective. In making our case we must clearly understand that the profession of architecture is ideologically entrenched in formalism and that what is so often missing from the standard model of practice today is consideration of the needs, interests and goals of the people who will directly use the built project as well as the larger community which may be impacted. Even when the client is consulted in earnest by the architect, many of the clients are never the ultimate occupants or users of the project and therefore may not represent interests other than their own. The essential point is that the users and the public are among the key stakeholders in architectural projects, but they are most often totally excluded or marginalized in today's design process.

In making our case we must also realize that architects in most instances do have considerable power to use a humanistic paradigm in their practice. Certainly some clients may initially want to dictate the design project to the architect and these clients may have little or no people-centered concerns. The professional architect, however, typically retains considerable influence from start to finish on projects and can play key roles as researcher, educator, negotiator, and facilitator. In our view, these roles should involve identifying and understanding the stakeholders' needs and interests, educating the client 
and remaining stakeholders about the implications of a proposed design, and facilitating negotiation and compromise when different interests occur between client and other stakeholders.

What about those rare cases where the client might rigidly and unflinchingly impose an architectural design that would result in an inhumane environment for the user? Given this ethical dilemma for the architect, the humanistic paradigm we propose would suggest that the architect should refuse to participate in the project (i.e., refuse from the very start). Of course, the counter-argument might well be "If your firm does not bid the project another firm will." The humanistic response suggests to architects that they should remain steadfast in refusing to participate because to do otherwise would violate the fundamental principles on which the paradigm rests (i.e., serving the needs of people and improving society). Another might argue that certain design structures are inhuman by their very function, such as jails and prisons, and question how an architect should respond to these projects. The architect should be reminded that despite the containment functions of such structures, there are vast differences between correctional facilities, some which are impersonal fortresses that dehumanize, punish, and destroy all human dignity, and others that contain people but within a designed environment that retains human dignity both for those contained and the larger society charged with the task of containment. If given no other choice by the client, the humanistic paradigm we propose would suggest that the architect should refuse to participate in making a "corrections house" horrors. The same may be true of mass assembly plants. Some are nothing more than "sweatshops" and others can provide the creature comforts entitled to all workers. Again, if the architect is given no design flexibility by a client who wants to build "sweatshops", the humanistic paradigm we propose would suggest that the architect refuse to participate in a project that perpetuates the abuse of laborers. Answers to ethical dilemmas like those discussed above are complex and of course even within a humanistic perspective there are differences on appropriate response, but at the very least it would be difficult to defend how the reputation of either an architectural firm or the profession of architecture could be advanced by participation in projects that continue or even worsen human problems.

While the architect most often does have direct power regarding design, most of us outside of architecture who propose a humanistic approach must realize that we have only the power to share knowledge and heighten awareness. Given these realities, we offer the following approaches that might convince professional architects to practice a greater balance between formalism and humanism.

1. A humanist approach not only has social capital advantages but also financial capital advantages for the architect. The human capital advantages of a humanistic paradigm are clear-greater responsiveness to client needs and new organizational forms, betterment of communities, and the increased status of the profession of architecture. Any serious appeal to architects for a humanistic approach, 
however, will need to consider that project costs and service fees are, and will continue to be, a major part of architectural practice. Therefore, while some humanists may deemphasize financial interests, the fact is that in order to make the needed changes in the profession they will need to demonstrate in convincing fashion to most practicing architects that there are also financial and not just human capital advantages with use of a humanistic approach. Toward this end, Davy and Harris (2001) and Hobbs (2001) suggest that architectural firms are now trapped in (1) An antiquated economic-based business model; (2) that this business model does not respond to many clients who are demanding a wider range of services and who are expecting collaborative participation with architects; and (3) That design professionals are quickly becoming marginalized as management consulting firms and construction firms have become formidable new competitors. We would argue that a humanistic approach could well lead to expanded "people-centered" business functions for architectural firms and thereby increase profits. These so called "full-service" firms could collaborate with or hire social scientists and expand to such areas as conducting surveys to identify the various stakeholders in a project, conducting needs and asset surveys, analyzing the organizations themselves that seek to reinvent themselves, and conducting evaluation research of finished projects. We would further argue to the professional architect that most "people-centered" research would be quite inexpensive relative to potential value. We would also maintain that as architects incorporate this kind of "people" information into the project design, they might well avoid post-construction problems, such as the "sick building syndrome" which is often directly blamed on the architect. In fact, both the financial costs and the reputational costs to a firm can be high when serious design errors are discovered after the project is completed. Cost-benefit analyses will have to be undertaken to validate the advantages of using a humanistic approach, but we are convinced that design firms have little to lose financially and potentially a great deal to gain-financially and socially-- by adding this humanistic perspective in their work.

\section{Previous "people-centered" theories and research findings have much to}

offer the professional architect. Among the hundreds of examples, a few of these theories and findings are offered here for architects to see the merits of a humanistic approach to design.

... Social research has shown that work performance among scientific workers increases with frequency of chance encounters, even when the scientists are involved in different projects and assigned to different work teams; thus encouraging the architect to design central meeting places where these types of workers could by chance meet, such as common dining areas and common meeting rooms (Gieryn 2002).

... A social research group has learned that student performance in both math and reading improves with the effect of daylighting; thus suggesting to the architect design of skylighting and window lighting in school settings (Heschong 1999).

... Research has identified the major contributing factors to "sick building syndrome." While some factors (i.e., use of poorly specified building materials, condensation or water leakage, and low efficiency of ventilation) are essentially design or 
construction issues, the remaining issues (i.e., low staff morale, lack of worker recognition, poor labor needs assessment, low level of facilities management, and high building occupancy) are directly related to organizational and management problems that could be assisted via social research and subsequent recommendations (Lorsh and Abdou 1994).

...Organizational culture theorists suggest that architectural design, including office layout, wayfinding systems, and colors and lighting, can encourage integrated cultures among organizational members as opposed to fragmented and conflicted cultures where members' values, strategies, visions, norms and beliefs are disparate and opposed. Physical design affects human interaction, access or closure to other people, collegial and open relationships or reinforcement of hierarchies, and inclusiveness or exclusiveness of membership, all which impact the organization's culture (Rapoport 2000 and Schein 1992).

...Urban sociologists as well as research conducted by the Urban Land Institute suggest the design of post World War II subdivisions undermined neighbor-to-neighbor interaction and citizen participation in community matters. The work suggests that architects and developers should design planned communities and housing types that are less sterile and homogeneous and encourage a sense of community (Herrington, 2003).

...Social scientists have examined the modern to postmodern transition in society accented by people experiencing increasingly compartmentalized and fragmented lives. One research study concluded that workers are increasingly seeking spirituality in the workplace; thus, architects are being asked to revamp workplaces to include sacred places, such as meditation rooms, chapels, gardens, and designed extensions to outdoor natural settings (Mitroff and Denton 1999).

\section{A humanistic perspective can contribute to every stage of the design}

process. Some time ago Sommer (1983) proposed that social design experts could assist the architect in the following areas: human use of space, awareness and environmental cognition, environmental preferences, user needs analysis, participatory design, and post occupancy evaluation. Today social scientists have built upon this tradition and have discussed the most applicable research methods for architectural design and the contributions that can be made at each step of the design process. The most applicable methods include survey research consisting of mailed questionnaires, personal interviews, focus group interviews, and telephone interviews; email surveys; GIS (Geographical Information System) research; field observation; unobtrusive measures such as behavioral mapping analysis and examination of physical traces; and secondary data previously gathered by another source (Bugni and Smith, 2002). The contributions of social scientists are apparent also at every stage of the design process, as illustrated below.

I. Predesign and Programming stages — assistance could be given on:

1. Baseline research (e.g., defining the problem, identifying the stakeholders, and collecting, analyzing and interpreting baseline data).

2. Needs and assets assessment of a group(s). 
3. Human factor analysis (e.g., collecting and analyzing demographic data, understanding roles and relationships, and understanding group members' beliefs, values and goals).

4. Organization-based analysis (e.g., analyzing the organizational culture, formal and informal goals, conflicts, structures and functions, and decision-making processes).

II. Design stage---assistance could be given on:

1. Analysis of social impact of the proposed design concept.

2. Analysis of the project team and the group dynamic.

3. Facilitation of the design team and user interactions.

III. Construction Stage---assistance could be given on:

1.Observation, feedback, and intervention suggestions on the architect-stakeholders relationship.

IV. Post-construction stage - assistance could be given on:

1. Post-occupancy evaluation (e.g., determining if the project supported the needs of the various stakeholders, such as workers, customers, managers, owners, neighborhood businesses, and larger community).

In all the methods and contributions suggested above, the focus is on understanding the person-physical design relationship and with the goal of humanizing the final design project.

\footnotetext{
4. Humanist scholars will need to initiate face-to-face dialogue and propose collaborative projects with those in architecture. Members of professional groups are usually unwilling to dismiss the paradigms they have learned and applied throughout their careers, and architects are no exception. Design professionals have enjoyed financial success over the years and have maintained a great deal of power to control the design project. Expectedly, it is just easier for them to defend the status quo. Criticisms about being too formalistic and commodity-driven and about being unresponsive to the needs of people can be easily cast aside. For these reasons there is no expectation that most architects will suddenly have a rapid change of mind about how they approach design.
}

The task to bring about change, then, mostly falls to those outside of architecture and the select few within architecture. One place for humanist scholars to begin is to approach schools of architecture and propose cross-listed social science courses that would educate future architects about social theories, related findings, and research methods. Alternatively, they could suggest that this material be incorporated into already existing architectural courses. Karen Franck (2000), an environmental psychologist currently teaching in the New Jersey School of Architecture, notes that architects are qualified to address the form and function of a building, but they are still not formally trained to understand the social impact of their design decisions. 
Another direct approach is for social scientists to propose to the professional architect collaborative research projects of use to both practioners and academic scholars/researchers. As previously discussed, architects only rarely approach social scientists for assistance on any aspect of design. Therefore, we feel that it is the social scientist who must initiate the "dance" with professional architects and work hard to ensure that the architect understands the benefits of using a people-oriented approach.

The authors of this paper have practiced what is here being argued. We have developed a productive working relationship among three entities - a highly regarded architectural firm, a university school of architecture, and a university department of sociology. We have had many conversations, shared ideas, and developed a strong sense of mutual respect and trust. As a result, we are developing cross-listed courses between architecture and sociology that will meet professional accreditation requirements and various team members have been invited to share the humanistic perspective with influential groups, including a Harvard School of Design project group, the Urban Land Institute, the American Sociological Association, and EDRA (Environmental Design Research Association). Our collaborative work has been profiled both in social science publications (ASA "Footnotes") and on the American Institute of Architecture website (see "Connections"). Our most ambitious project has been a submission for the American Institute of Architects Latrobe Fellowship Grant. Our proposed research and projects would include surveys of architectural schools as well as graduate level social science programs about existing curriculum that might focus on the humanistic paradigm as related to architecture; an international symposium of invited social scientists and architects to discuss people-centered design research, practice, and education; studies of exemplary architecture firms that are now employing the humanistic perspective; and a website for designed environment-people resources.

Our approach to humanizing architecture is not just another call for action among the many calls that have been made before, but it is intended to be an actual demonstration that the social sciences have something to offer the design world, that people matter, and that architecture as a profession can benefit. In conducting this work, we will also be helping ourselves (i.e., the social sciences) by testing if our theories related to design actually do explain and predict or whether some should be modified or perhaps new ones developed. Both the profession of architecture and the social sciences will win during this process, but the biggest winners will be people.

\section{REFERENCES}

Arendt, Hannah. 1958. The Human Condition. Chicago: University of Chicago Press. 
Arnheim, Rudolf. 1977. The Dynamics of Architectural Practice. Berkeley, CA: University of California Press.

Baudrillard, Jean. 1981. For a Critique of the Political Economy of the Sign. St. Louis: Telos Press.

Becker, Frank and Fritz Steel. 1985. Workplace by Design: Mapping the High Performance Workplace. San Francisco: Jossey- Bass.

Bordieu, P. 1990. The Logic of Practice. Stanford, CA.: Stanford University Press.

Brown, Jonathan D. 1998. The Self. Boston, MA: McGraw Hill.

Bugni, Valerie and Ronald W. Smith. 2002. "Getting to a Better Future Through Architecture and Sociology." American Institute of Architects, AIA Footnotes Newsletter. May.

Bugni, Valerie and Ronald W. Smith. 2002. "Combining Architecture and Sociological Research Methods, American Institute of Architects, AIA Footnotes Newsletter. July.

Burrell, Gibson, ed. 2002, "The Rise of Objects in the Study of Organizations," Organizations 9:357-488.

Butrell, Frederick H. "New Directions in Environmental Sociology," Annual Review of Sociology. 13:465-488.

Catton, William R., Jr. and Riley E. Dunlap. 1978. "Environmental Sociology: A New Paradigm," American Sociologist 13:41-49.

Churchill, Winston. 1944. "Rebuilding the House of Commons" in Charles Eades Onward to Victory. Boston, MA: Little, Brown and Company.

Crumley, Carole L., A. Elizabeth van Deventer, and Joseph J. Fletcher (eds.), New Directions in Anthropology and Environment: Intersections. Walnut Creek, CA:

AltaMira Press.

Csikszentmihalyi, M. and Rochberg-Halton, E. 1981. The Meaning of Things. Cambridge: Cambridge University Press.

Cuff, Dana. 1996. Architecture: The Story of Practice, 5th ed. Boston, MA: MIT Press. Davis, Douglas. 1971. “New Architecture,” Newsweek (April 19): 78. 
Davy, Kyle and Susan Harris. 2001. "A Search for New Models of Practice," San Francisco: Advanced Management Institute for Architecture and Engineering.

DeYoung, R. 1999. "Environmental Psychology,” in D.E. Alexander and R.W. Fairbridge (eds.), Encyclopedia of Environmental Science. Hingham, MA: Kluwer Academic Publishers.

Dixon, John Morris. 2003. "P/A Awards at 50: A History of What's Next," Architecture (website www.architecturemag, Design and Trends subsection, February 9).

Dubois, William D. 2001. "Design and Human Behavior: Sociology of Architecture," in Applying Sociology: Making a Better World. Boston, MA: Allyn and Bacon.

Dubois, William D. and R, Dean Wright, eds. 2001. Applying Sociology: Making a Better World. Boston, Boston, MA: Allyn and Bacon.

Franck, Karen and Bianca Lepori. 2000. Architecture Inside Out. London: WileyAcademy.

Gagliardi, Pasquale. 1996. "Exploring the Aesthetic Side of Organizational Life," in S. Clegg, C. Hardy and W. Nord (eds.), Handbook of Organization Studies. London: Sage Publications.

Giddens, A. 1990. Consequences of Modernity. Stanford, CA.: Stanford University Press.

Gieryn, Thomas F. 2002 "What Buildings Do," Theory and Society 31:35-74.

Gieryn, Thomas F. 2000. "A Place for Space in Sociology," in Annual Review of Sociology, vol. 26, Palo Alto, CA.: Annual Reviews Inc.

Gifford, Robert. 2002. Environmental Psychology: Principals and Practice, 3rd ed. Canada: Optimal Books.

Goffman, Erving. 1959. The Presentation of Self in Everyday Life. New York: Doubleday.

Gottdiener, Mark and Ray Hutchison. 2000. The New Urban Sociology. Boston: McGraw-Hill.

Hatch, Mary Jo. 1997. Organization Theory. New York: Oxford University Press.

Hawley, Amos H. 1986. Human Ecology: A Theoretical Essay. Chicago: University of Chicago Press. 
Handy, Charles. 1995. “Trust and the Virtual Organization." Harvard Business Review 73: 40-50.

Herrington, Brent. 2003. Urban Land Institute. Personal correspondence with V. Bugni.

Hershberger, Robert. 1999. Architectural Programming and Predesign Manager. NY: McGraw Hill.

Heschong, Lisa. 1999. Daylighting in Schools. Fair Oaks, CA: Pacific Gas and Electric Company.

Hobbs, Richard, FAIA.2001. “Are You the Client's Trusted Advisor.” Design Intelligence.wwwgreenwayconsulting.com/articles/clients_trusted_advisor.htm.

Homans, George. 1950. The Human Group. New York: Harcourt Brace and World.

Jaffee, David. 2001. Organizational Theory: Tension and Change. Boston: McGraw-Hill.

James, William 1890. The Principles of Psychology. Vol. 1. NY: Holt.

Lorsch, H.G. and O.A. Abdou. 1994. "The Impact of the Building Indoor Environment on Occupational Productivity, Part 1-Recent Studies, Measures and Costs," ASHRAE trans. 100(2): 741-749.

Mayo, Elton. 1945. The Social Problems of an Industrialized Civilization. The Graduate School of Business Administration: Harvard University.

Mead, George Herbert. 1934. Mind, Self, and Society. Chicago, IL: The University of Chicago Press.

Mead, George Herbert. 2002 [1932]. The Philosophy of the Present. Chicago, IL: Open Court Publishing Company.

Mitroff, Ian and Elizabeth A. Denton. 1999. A Spiritual Audit of Corporate America: A Hard Look at Spirituality, Religion, and Values in the Workplace. San Francisco: Jossey Bass Publishers.

Montana, P. 1993. "Management.” Barron's Business Review Series. Woodbury, NY.

Park, Robert. 1936. “Human Ecology.” American Journal of Sociology. 42:1-15. 
Rapoport, Amos. 1990. The Meaning of the Built Environment: A Nonverbal Communication Approach. Beverly Hills, CA: Sage.

Rochberg-Halton, E. 1979. "The Meaning of Personal Art Objects,” in J. Zuzanek (ed.), Social Research and Cultural Policy. Waterloo, Ontario: Otium.

Schein, Edgar. 1992. Organizational Culture and Leadership. San Francisco, CA: Jossey-Bass, Inc. Publishers.

Smith, David A. and Michael F. Timberlake, "Urban Political Economy," in John Palen, The Urban World. New York :McGraw-Hill, 1997.

Sommer, Robert. 2001. Personal correspondence to V. Bugni.

Sommer, Robert. 1969. Personal Space: The Behavior Basis of Design. Englewood Cliffs, NJ: Prentice-Hall.

Sommer, Robert. 1980. "Architecture, Psychology: The Passion has Passed.” AIA Journal, April: 76-82.

Sommer, Robert. 1983. Social Design: Creating Buildings with People in Mind. Englewood Cliffs, NJ: Prentice-Hall.

Stallworth, O. and Kleiner, B. (1996). "Recent Developments in Office Design," Facilities, Vol. 14.

Steele, Fritz. 1983. Making and Managing High-quality Workplaces. New York: Teachers College Press.

Steele, Fritz. 1973. Physical Settings and Organizational Development. Reading, MA: Addison-Wesley.

Stryker, Sheldon. 1959. "Symbolic Interaction as an Approach to Family Research," Marriage and Family Living. 21: 111-119.

Urry, John. 1991. "Time and Space in Giddens' Social Theory," in C. Bryant and D. Jarry (eds.), Giddens' Theory of Structuration: A Critical Appreciation. London: Routledge.

Weick, Karl E. 1995. Sensemaking in Organizations. Thousand Oaks, CA: Sage. 
Humanity and Society - 20 